\title{
Molecular characterization of phytoplasmas of 'Clover proliferation' group associated with three ornamental plant species in India
}

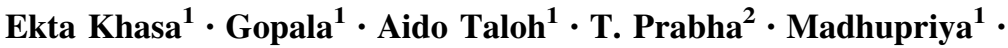 \\ G. P. Rao ${ }^{1}$
}

Received: 26 September 2016/Accepted: 31 October 2016/Published online: 11 November 2016

(c) The Author(s) 2016. This article is published with open access at Springerlink.com

\begin{abstract}
Suspected phytoplasma symptoms of little leaf, yellowing, chlorosis, phyllody, witches' broom, and stunting were observed on ten different ornamental plant species at New Delhi, Andhra Pradesh, Haryana, Bengaluru, and Pune, India, during March to July 2016. To investigate the possibility of phytoplasma etiology, PCR assays were performed using universal primer pairs (P1/P7 followed by $3 \mathrm{Far} / 3 \mathrm{Rev}$ ) specific to the phytoplasma $16 \mathrm{Sr}$ $R N A$ gene. First round PCR amplification with primer pair $\mathrm{P} 1 / \mathrm{P} 7$ did not yield expected $1.8 \mathrm{~kb}$ product of $16 \mathrm{~S}$ rRNA region from any of the 17 symptomatic samples. However, $1.3 \mathrm{~Kb}$ amplicons were observed in nested PCR assays with 3Far/3Rev primer pair in symptomatic leaf samples of Hibiscus rosa-sinensis L. (Pune isolate), Saponaria officinalis L. (Pune isolate), and Allamanda cathartica L. (Delhi isolate). No amplifications were observed in any of the other tested symptomatic and non-symptomatic plant samples either in first round or second round of nested PCR assays with phytoplasma specific primer pairs. Pairwise sequence comparison of $16 \mathrm{~S}$ rDNA sequences of the five positive phytoplasma strains of A. catharica, H. rosa-sinensis, and $S$. officinalis in the present study revealed 99-100\% sequence identities with strains of 'clover proliferation' (16SrVI) group. Phylogenetic and virtual RFLP analysis of $16 \mathrm{~S}$ rDNA sequences of the five identified phytoplasma strains belonging to three ornamental species further confirmed their clustering and grouping with
\end{abstract}

G. P. Rao

gprao_gor@rediffmail.com

1 Division of Plant Pathology, Indian Agricultural Research Institute, Pusa Campus, New Delhi 110012, India

2 Directorate of Floricultural Research College of Agriculture, MPKV, Shivajinagar, Pune 411005, India member strains of 'clover proliferation' subgroup D. This is the first record of the phytoplasma association of 'clover proliferation' subgroup D with $H$. rosa-sinensis, S. officinalis, and A. cathartica in the world.

Keywords Hibiscus rosa-sinensis L. · Saponaria officinalis L. · Allamanda cathartica L. · Phytoplasma . 16Sr VI-D subgroup · Identification · India

\section{Introduction}

Phytoplasmas, formerly known as mycoplasma-like organisms (MLOs), are cell wall less Mollicutes that colonize plant phloem sieve tube elements and insects gut wall. They are known to cause devastating losses in crops and natural ecosystems worldwide. They are transmitted from one plant to another by phloem-feeding insects, primarily leafhoppers, plant hoppers, and psyllids (Bertaccini et al. 2014). Phytoplasmas cause diseases in several commercial ornamental plants causing serious economic losses all over the world. Phytoplasma diseases are the major constraint in commercial ornamental plant production by lowering the quantum and quality gaining international importance. Phytoplasma causes different symptoms of general yellowing and stunting of plants, proliferation of shoots, phyllody, virescence, reduced size of flowers in many ornamental plants which affects their economic value (Chaturvedi et al. 2010; Bertaccini 2015). The ' $C a$. P. asteris' $16 \mathrm{SrI}$ group is the major group infecting ornamental species worldwide. So far, more than 60 ornamental plant species have been reported to be infected with phytoplasma worldwide (Madhupriya 2016).

During a recent survey in five states (New Delhi, Andhra Pradesh, Haryana, Bengaluru, and Pune) of India, 
phytoplasma suspected symptoms were observed on 17 plants belonging to ten different ornamental plant species (Table 1). Attempts were made to confirm the phytoplasma etiology with the 17 symptomatic plants in the present study by PCR assays, phylogeny, and RFLP analysis.

\section{Materials and methods}

\section{Survey and symptomatology}

Surveys of garden, nurseries, and experimental field/plots at New Delhi, Andhra Pradesh, Haryana, Bengaluru, and Pune was made during March to July 2016, and phytoplasma suspected symptoms were collected from 17 plants of ten different ornamental species, viz. A. cathartica, $B$. glabra, Y. aloifolia, C. infundibuliformis, $H$. italicum, $H$. rosa-sinensis, T. erecta, W. tinctoria, S. officinalis, and Xanthostemon chrysanthus (Table 1).

\section{DNA extraction}

DNA from three healthy and three symptomatic plant tissues (midrib and leaf veins) of 17 ornamental samples were extracted following a described procedure (Ahrens and Seemuller 1992). Amplification of phytoplasma ribosomal DNA (rDNA) was performed with the universal phytoplasma primer pairs P1/P7 (Deng and Hiruki 1991; Schneider et al. 1995). Further nested PCR assays were performed with primer pairs 3Far/3Rev (Manimekalai et al. 2010). The DNA isolated from toria phyllody phytoplasma infected Catharanthus roseus leaf tissue (Azadvar and Baranwal 2012) was used as positive control.

PCR reactions were carried out in a thermal cycler (Eppendorf, Germany) and the cycling protocol used for the first round PCR using $\mathrm{P} 1 / \mathrm{P} 7$ primer pair with initial denaturation at $94{ }^{\circ} \mathrm{C}$ for $5 \mathrm{~min}$, followed by 35 cycles consisting of denaturation at $94{ }^{\circ} \mathrm{C}$ for $45 \mathrm{~s}$, annealing at $55^{\circ} \mathrm{C}$ for $1 \mathrm{~min}$. and extension at $72{ }^{\circ} \mathrm{C}$ for $2 \mathrm{~min}$, with the final extension for $10 \mathrm{~min}$ at $72{ }^{\circ} \mathrm{C}$. Total PCR mixture $(50 \mu \mathrm{l})$ contained $100 \mathrm{ng} / \mu \mathrm{l}$ of total nucleic acid, $20 \mathrm{pmol}$ of 3 Far/3Rev primers, 1.0 unit of Taq DNA polymerase (G-biosciences), $0.2 \mathrm{mM}$ of dNTP, $2.0 \mathrm{mM}$ $\mathrm{MgCl}_{2}$, and $1 \mathrm{X}$ PCR buffer. Two $\mu$ l of product of the first round of PCR was used in nested PCR using internal primer pairs 3Far/3Rev (Manimekalai et al. 2010). Reaction mixture and condition of nested PCR used were similar as first round PCR except for annealing at $63{ }^{\circ} \mathrm{C}$ for $1 \mathrm{~min}$. The PCR product was subjected to electrophoresis in a $1.0 \%(\mathrm{w} / \mathrm{v})$ agarose gel, stained with ethidium bromide, and observed under UV transilluminator.

\section{Sequencing and BLAST analysis}

The $\sim 1.3 \mathrm{~kb}$ nested PCR products were sequenced directly in both directions using 3Far/3Rev primers. The sequences were assembled using DNA baser V.4 program and were further aligned using CLUSTAL $\mathrm{W}$ method of Bio-Edit software. Aligned sequences were deposited in NCBI GenBank and used as query sequence in BLASTn search analysis with related submitted sequences in GenBank.

\section{Phylogenetic analysis}

The 16S rDNA sequence generated from the present study and reference phytoplasma strains sequence retrieved from GenBank were used to construct phylogeny by neighborjoining method with 1000 replications for each bootstrap value using the MEGA 6.0 software version for ' $C a n d i$ datus Phytoplasma species' assignment (Tamura et al. 2013). Acholeplasma laidlawii was used as out group to root the phylogenetic tree.

\section{In silico RFLP analysis}

The phytoplasma sequences corresponding to the 3Far/ 3Rev region was subjected to in silico RFLP analysis using pDRAW32 program developed by AcaClone Software (http://www.acaclone.com) and compared with representative sequences of the mollicutes sp. phytoplasma $16 \mathrm{Sr}$ VI-D (Ac. No. X83431) subgroup for assigning 16Sr subgroups to ornamental phytoplasma strains analysed by the same restriction mapping utilizing AcaClone software generated RFLP sequences.

\section{Results and discussion}

\section{Survey and symptomatology}

During survey of garden nurseries and experimental field/plots in New Delhi, Andhra Pradesh, Haryana, Bengaluru, and Pune, phytoplasma suspected symptoms of little leaf, yellowing, chlorosis, phyllody, witches' broom, and stunting of plants were recorded on ten different ornamental plants species, viz. A. cathartica, B. glabra, $Y$. aloifolia, $C$. infundibuliformis, $H$. italicum, $H$. rosa-sinensis, T. erecta, W. tinctoria, S. officinalis, and Xanthostemon chrysanthus (Fig. 1; Table 1).

\section{Detection of phytoplasma by PCR assays}

First round PCR amplification did not yield the expected $1.8 \mathrm{~kb}$ product of the $16 \mathrm{~S}$ rRNA region from any of the 17 


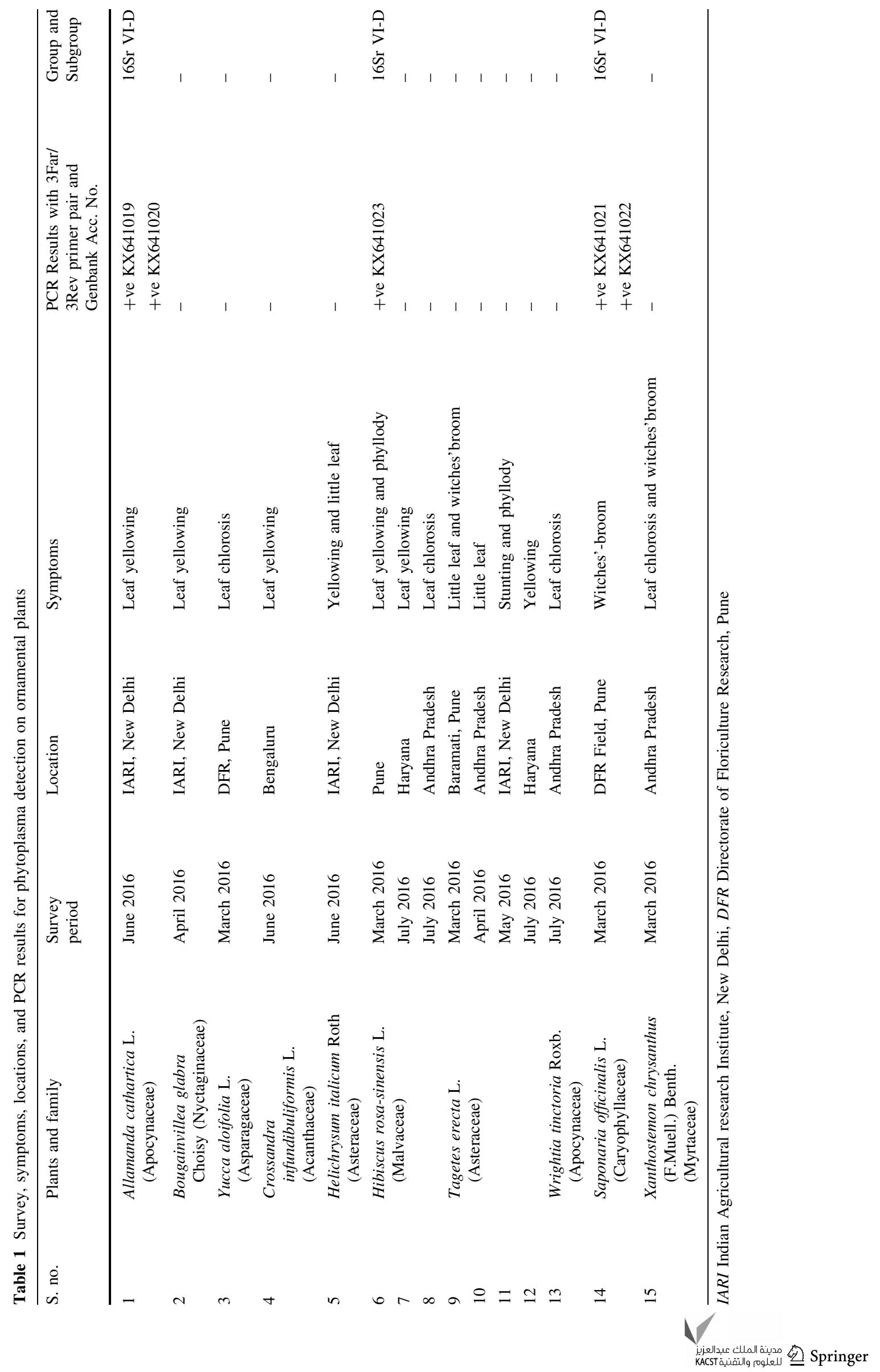




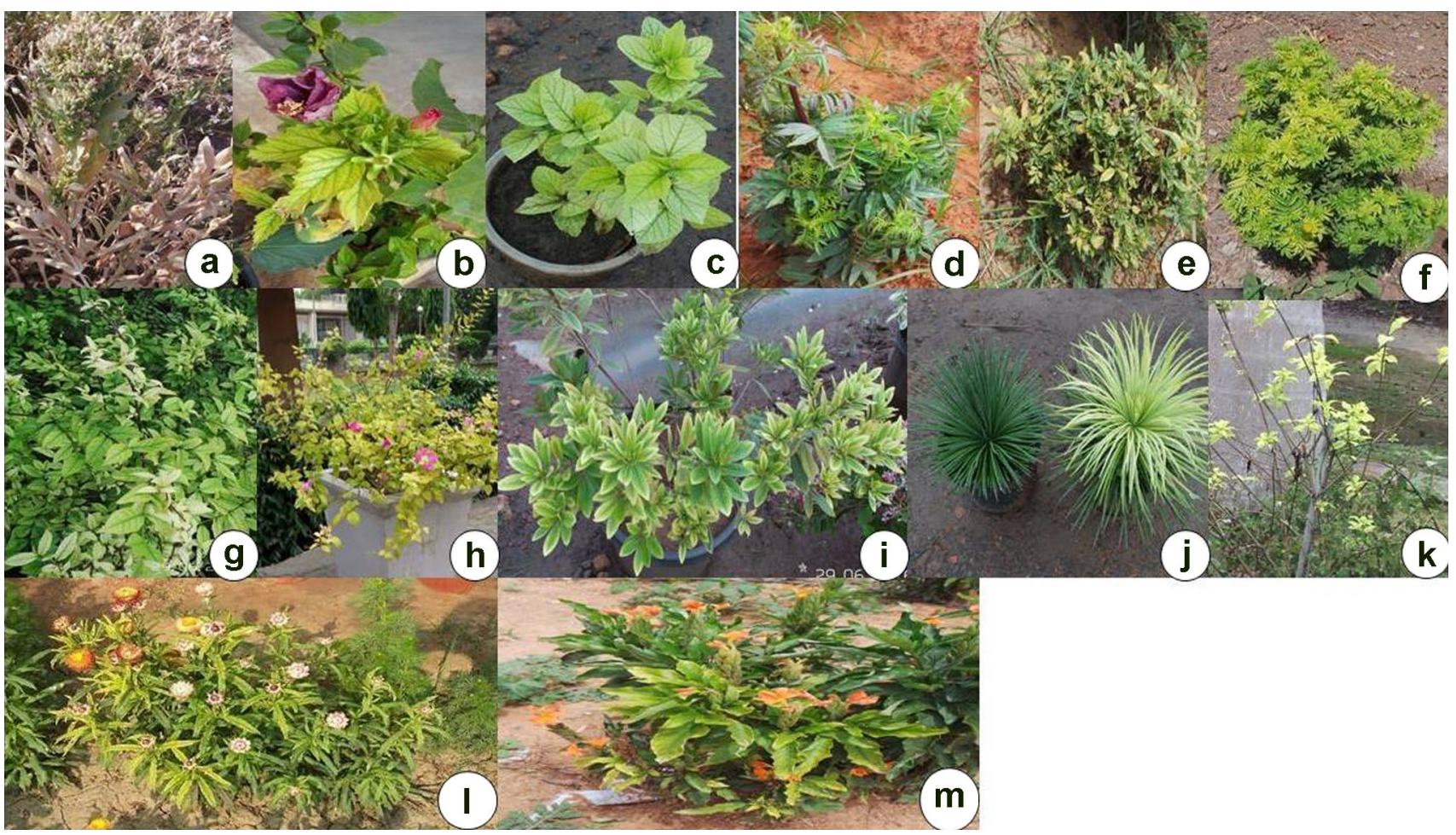

Fig. 1 Phytoplasma suspected symptoms on different ornamental plant species a Witches' broom in Saponaria officinalis at Pune; b Leaf yellowing and phyllody in Hisbiscus rosa-sinensis at Pune. c Leaf chlorosis in H. rosa-sinensis at Andhra Pradesh. d Little leaf in Tagetes erecta at Andhra Pradesh; e stunting and phyllody in Tagetes erecta at Delhi. $\mathbf{f}$ Little and witches'broom in Tagetes erecta at Pune; g leaf chlorosis in Wrightia tinctoria at Rajahmundary, Andhra
Pradesh. h Leaf yellowing in Bougainvillea glabra at Delhi; i leaf chlorosis and witches'broom in Xanthostemon chrysanthus at Rajahmundary, Andhra Pradesh, $\mathbf{j}$ Leaf chlorosis in Yucca aloifolia at Pune. $\mathbf{k}$ Leaf yellowing in Allamanda cathartica at Delhi. I Leaf yellowing in Helichrysum italicum at Delhi. m Leaf yellowing in Crossandra infundibuliformis at Bengaluru
Fig. 2 Phylogenetic tree constructed by neighbor-joining method showing the relationships among $H$. rosasinensis, S. officinalis and $A$. cathartica, and the reference phytoplasma strains. Accession numbers are specified in the tree. A. laidlawii was used as an out group

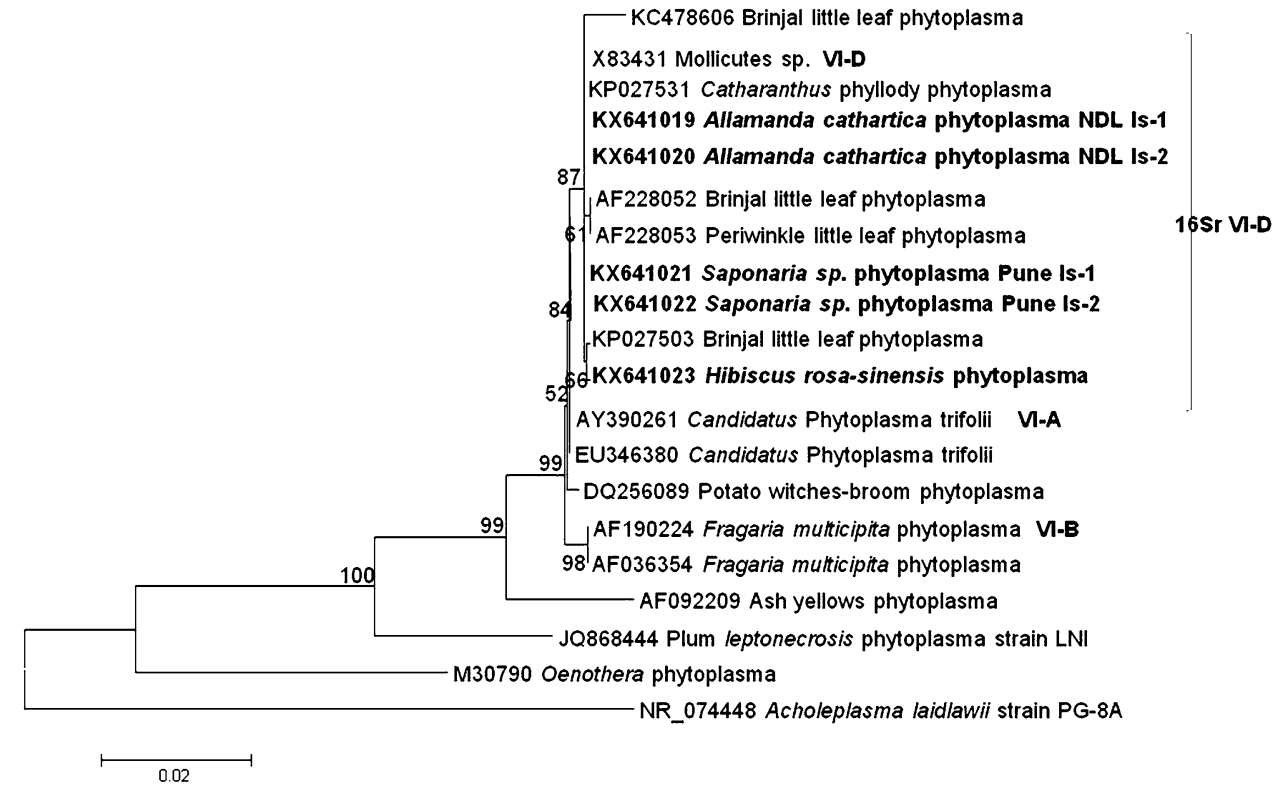

symptomatic ornamental test samples with primer pair P1/ P7 (data not shown). However, $1.3 \mathrm{~Kb}$ amplicons were observed in nested PCR assays with 3Far/3Rev primer pair in five symptomatic plants samples of the three test ornamental species, $H$. rosa-sinensis (one isolate, Pune), $S$. officinalis (two isolates, Pune) and A. cathartica (two 

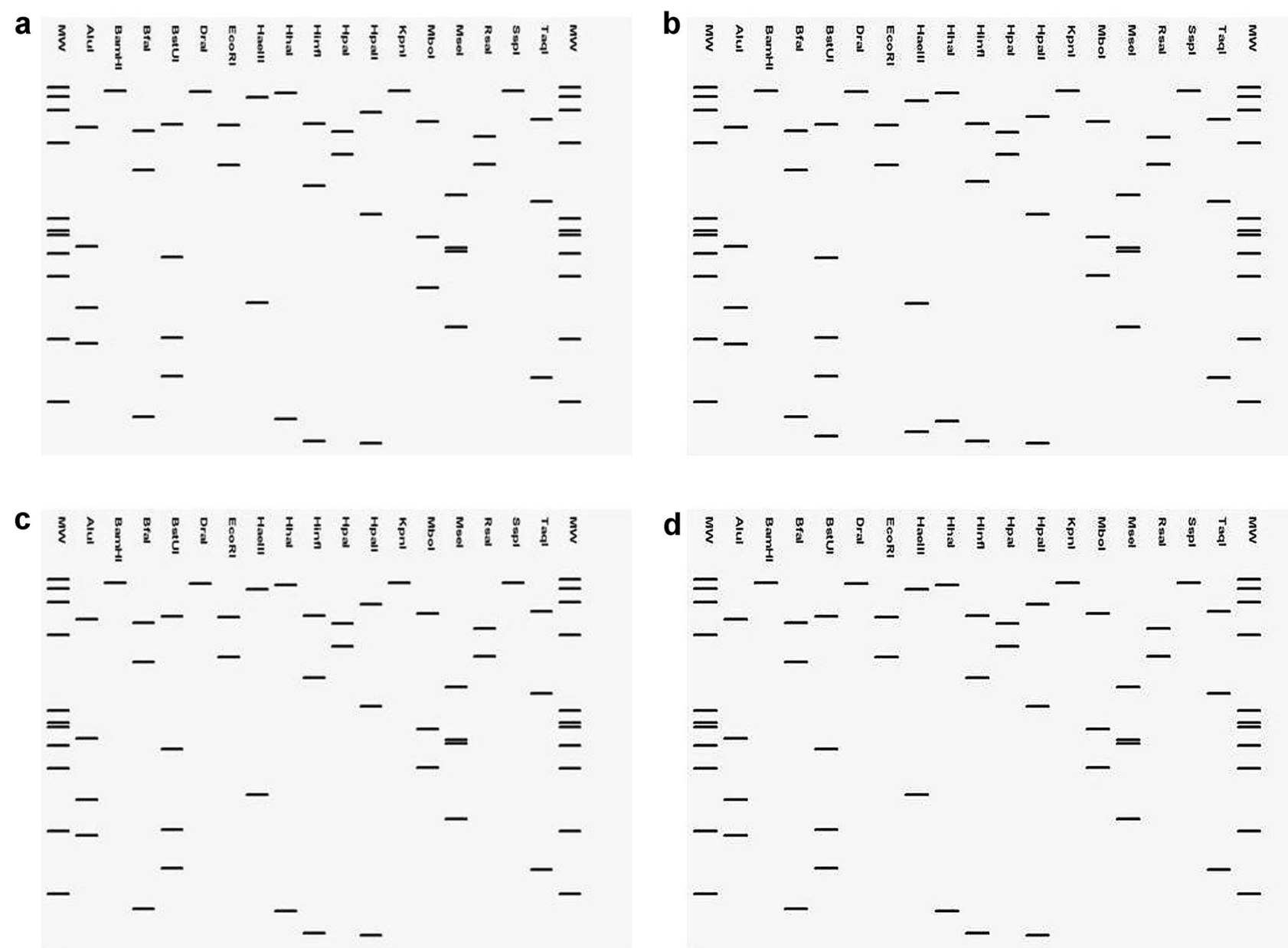

Fig. 3 Comparison of virtual RFLP patterns derived from in silico digestions of $1.3 \mathrm{~kb} 16 \mathrm{~S}$ rDNA sequences of a Brinjal little leaf phytoplasma 16SrVI-D (X83431), b S. officinalis L. (KX641021), c $H$. rosa-sinensis L. (KX641023), and d A. cathartica L.

isolates, Haryana) and the positive control of toria phyllody phytoplasma infected Catharanthus roseus leaf tissue (Azadvar and Baranwal 2012). No amplifications were observed in any of the rest twelve symptomatic ornamental samples and the non-symptomatic samples (Table 1).

Nested PCR products of five positive amplified products were directly sequenced, and the partial $16 \mathrm{Sr} R N A$ sequences of $1326,1258,1333,1339$, and $1252 \mathrm{bp}$, respectively, were deposited in the GenBank database under the Accession numbers as A. cathartica (KX641019, KX641020), H. rosa-sinensis (KX641023), and S. officinalis (KX641021, KX641022) (Table 1).

\section{Sequence analysis and phylogenetic relationships}

Pairwise sequence comparison of the partial $16 S$ rRNA gene sequences of the five positive ornamental phytoplasma strains of $H$. rosa-sinensis, $S$. officinalis, and $A$. cathartica revealed 99\% (H. rosa-sinensis L. Acc No.

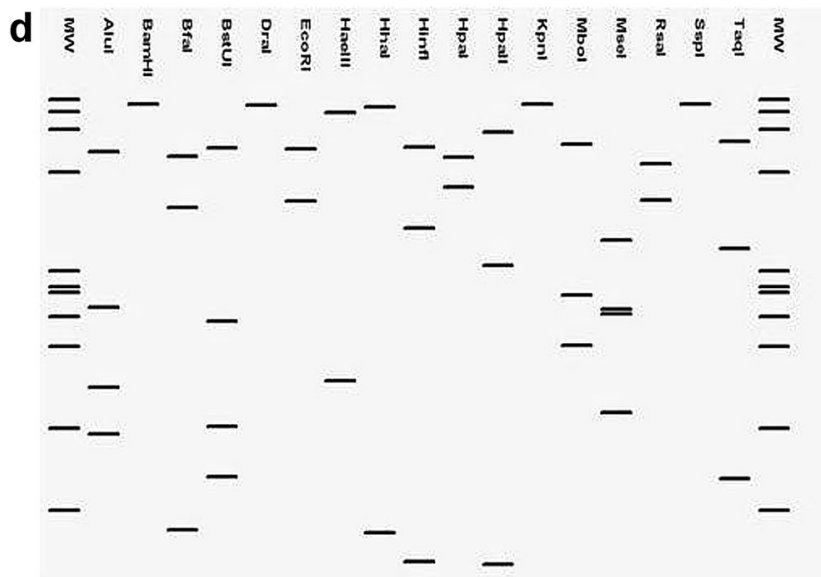

(KX641019) digested using 17 different restriction endonucleases indicating that the A. cathartica L., $H$. rosa-sinensis L., and $S$. officinalis L. phytoplasma belonged to $16 \mathrm{Sr}$ VI-D phytoplasma subgroup

KX641023) and $100 \%$ (A. cathartica L. Acc No. KX641019, KX641020; Saponaria officinalis L., Acc No. KX641021, KX641022) sequence identity with strains of clover proliferation. Phylogenetic analysis based on $16 \mathrm{~S}$ rDNA sequences of all the five ornamental phytoplasma strains in the present study revealed their close relationship with strains of clover proliferation group (16SrVI) (Fig. 2).

\section{In silico RFLP analysis and phytoplasma classification}

The phytoplasma sequence corresponding to the $3 \mathrm{Far} / 3 \mathrm{Rev}$ region was subjected to in silico restriction enzyme digests and virtual gel plotting using the pDRAW32 program developed by AcaClone Software (http://www.acaclone. com). Comparison of restriction site maps with 17 restriction enzymes (AluI, BamHI, BfaI, Bst $\mathrm{UI}$ (ThaI), DraI, EcoRI, HaeIII, HhaI, HinfI, HpaI, HpaII, KpnI, Sau3AI (MboI), MseI, RsaI, SspI, and TaqI) through pDraw

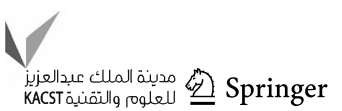


analysis revealed that the all the three positive ornamental phytoplasma strains (H. rosa-sinensis KX641023, A. cathartica KX641019, and Saponaria officinalis, KX641021) produced a virtual RFLP profile identical to phytoplasma reference strain mollicutes sp. phytoplasma (X83431, 16Sr VI-D subgroup) (Fig. 3). Therefore, phytoplasma strains from all the three ornamental plant species in the present study were classified under $16 \mathrm{Sr}$ VI-D subgroup.

So far, eleven different groups (16SrI, 16SrII, 16SrIII, 16SrV, 16SrVI, 16SrVII, 16SrIX, 16SrX, 16SrXII, 16 SrXIII, and 16SrXIV) of phytoplasmas were identified in ornamental plants in the world (Chaturvedi et al. 2010; Madhupriya 2016). Out of these eleven groups, the $16 \mathrm{Sr}$ I group is the most dominant group infecting major ornamental species in India (Chaturvedi et al. 2009; Madhupriya 2016). In the present study, we have reported occurrence of $16 \mathrm{SrVI}$ group on three ornamental plants species. In India, 16SrVI group of phytoplasmas was earlier reported to be associated with several diseases of plants, viz. Araucaria little leaf (Gupta et al. 2009), brinjal little leaf (Azadvar and Baranwal 2012), Withania little leaf (Zaim and Samad 1995; Samad et al. 2006), Portulaca little leaf (Samad et al. 2008), Datura little leaf (Raj et al. 2009; Singh et al. 2012), Croton leaf yellows (Madhupriya et al. 2016), and Calotropis gigantea leaf yellows (Madhupriya et al. 2010). However, 16SrVI-D subgroup of phytoplasma was only reported with brinjal little leaf (Azadvar and Baranwal 2012) and Catharanthus roseus little leaf (Bertaccini 2015). Hence, in our study, all the three ornamental species are new host records of clover proliferation' subgroup D in the world. There is a possibility of natural transmission of the 16Sr VI-D subgroup phytoplasma from ornamental species to brinjal crops which is already reported as natural host of 16Sr VI-D subgroup phytoplasma in India (Kumar 2015).

\begin{abstract}
Acknowledgements The authors are thankful to the ICAR-Extramural Research Project for providing financial assistance during the course of the study. The authors also wish to express sincere thanks to the Head, Division of Plant Pathology and the Director, Indian Agricultural Research Institute for providing laboratory facilities.
\end{abstract}

\section{Compliance with ethical standards}

Conflict of interest The authors declare that they have no conflict of interest.

Open Access This article is distributed under the terms of the Creative Commons Attribution 4.0 International License (http:// creativecommons.org/licenses/by/4.0/), which permits unrestricted use, distribution, and reproduction in any medium, provided you give appropriate credit to the original author(s) and the source, provide a link to the Creative Commons license, and indicate if changes were made.

\section{References}

Ahrens U, Seemuller E (1992) Detection of DNA of plant pathogenic mycoplasma like organisms by a polymerase chain reaction which amplifies a sequence of the $16 \mathrm{~S}$ rRNA gene. J Phytopathol $82: 828-832$

Azadvar M, Baranwal VK (2012) Multilocus sequence analysis of phytoplasma associated with brinjal little leaf disease and its detection in Hishimonus phycitis in India. Phytopathogenic Mollicutes 2(1):15-21

Bertaccini A (2015) Phytoplasma research between past and future: what directions? Phytopathogenic Mollicutes 5:S1-S4

Bertaccini A, Duduk B, Paltrinieri S, Contaldo N (2014) Phytoplasmas and phytoplasma diseases: a severe threat to agriculture. Am J Plant Sci 5(12):46-62

Chaturvedi Y, Singh M, Rao GP, Snehi SK, Raj SK (2009) First report of association of 'Candidatus phytoplasma asteris' (16SrI group) with little leaf disease of rose (Rosa alba) in India. Plant Pathol 58:788

Chaturvedi Y, Rao GP, Tiwari AK, Duduk B, Bertaccini A (2010) Phytoplasma on ornamentals: detection, diversity and management. Acta Phytopathol Entomol Hungarica 45:31-69

Deng S, Hiruki C (1991) Amplification of 16S rRNA genes from culturable and nonculturable mollicutes. J Microbiol Methods 14:53-61

Gupta MK, Samad A, Shasany AK, Ajayakumar PV, Alam M (2009) First report of a 16SrVI 'Candidatus Phytoplasma trifolii' isolates infecting Norfolk Island pine (Araucaria heterophylla) in India. Plant Pathol 59:399

Kumar M (2015) Genetic diversity and natural spread sources of brinjal little leaf phytoplasma, MSc thesis. IARI, New Delhi, pp 153

Madhupriya (2016) Molecular characterization of phytoplasmas associated with important ornamental plant species in Northern India. Thesis submitted at Amity University, Haryana

Manimekalai R, Soumya VP, Kumar RS, Selvarajan R, Reddy K, Thomas GV, Sasikala M, Rajeev G, Baranwal VK (2010) Molecular detection of $16 \mathrm{SrXI}$ group phytoplasma associated with root (wilt) disease of coconut (Cocos nucifera) in India. Plant Dis 94:636

Priya M, Chaturvedi Y, Rao GP, Raj SK (2010) First report of phytoplasma 'Candidatus Phytoplasma trifolii' (16SrVI) group associated with leaf yellows of Calotropis gigantea in India. New Dis Rep 22:29

Priya M, Tiwari AK, Rao GP (2016) First molecular identification of 'candidatus phytoplasma trifolii' (16SrVI-D) in croton bonplandianum from India. J Plant Pathol 98(1):171-185

Raj SK, Snehi SK, Kumar S, Khan MS (2009) First finding of 'Candidatus Phytoplasma trifolii' (16SrVI group) associated with little leaf disease of Datura inoxia in India. Plant Pathol $58: 791$

Samad A, Shasany AK, Gupta S, Ajayakumar PV, Darokar MP, Khanuja SPS (2006) First report of a 16SrVI group phytoplasma associated with witches'-broom disease on Withania somnifera. Plant Dis 90:248

Samad A, Ajayakumar PV, Shasany AK, Gupta MK, Alam M, Rastogi S (2008) Occurrence of a clover proliferation (16SrVI) group phytoplasma associated with little leaf disease of Portulaca grandiflora in India. Plant Dis 92:832

Schneider B, Seemueller E, Smart CD, Kirkpatrick BC (1995) Phylogeneticclassification of plant pathogenicmycoplasma-like organisms or phytoplasmas. In: Razin S, Tully JG (eds) Molecular and diagnostic procedures in mycoplasmology, vol 1. Academic Press, San Diego, pp 369-380 
Singh N, Madhupriya Rao GP, Upadhyaya PP (2012) 'Candidatus Phytoplasma trifoli' associated with little leaf and witches' broom disease of Datura stramonium L. India. Phytopathogenic Mollicutes 2(2):69-71

Tamura K, Stecher G, Peterson D, Filipski A, Kumar S (2013) MEGA6: molecular evolutionary genetics analysis (MEGA) software version 6.0. Mol Biol Evol 30:2725
Zaim M, Samad A (1995) Association of phytoplasmas with a witches-broom disease of Withania somnifera (L.) Dunai in India. Plant Sci 109:225-229 